\title{
The cost of adult liver transplantation in a referral center in Southern Brazil
}

\author{
Adriane B de SOUZA¹, Santiago RODRIGUEZ¹, Fábio Luís da MOTTA², Ajacio B de Mello BRANDÃ01,3 and \\ Claudio Augusto MARRONI',3
}

Received 7/2/2019 Accepted 2/4/2019

\begin{abstract}
Background - Liver transplantation (LTx) is the primary and definitive treatment of acute or chronic cases of advanced or end-stage liver disease. Few studies have assessed the actual cost of LTx categorized by hospital unit. Objective - To evaluate the cost of LTx categorized by unit specialty within a referral center in southern Brazil. Methods - We retrospectively reviewed the medical records of 109 patients undergoing LTx between April 2013 and December 2014. Data were collected on demographic characteristics, etiology of liver disease, and severity of liver disease according to the Child-Turcotte-Pugh (CTP) and Model for End-stage Liver Disease (MELD) scores at the time of LTx. The hospital bill was transformed into cost using the full absorption costing method, and the costs were grouped into five categories: Immediate Pretransplant Kit; Specialized Units; Surgical Unit; Intensive Care Unit; and Inpatient Unit. Results - The mean total LTx cost was US\$ 17,367. Surgical Unit, Specialized Units, and Intensive Care Unit accounted for 31.9\%, 26.4\% and 25.3\% of the costs, respectively. Multivariate analysis showed that total LTx cost was significantly associated with CTP class $\mathrm{C}(P=0.001)$ and occurrence of complications $(P=0.002)$. The following complications contributed to significantly increase the total LTx cost: septic shock $(P=0.006)$, massive blood transfusion $(P=0.007)$, and acute renal failure associated with renal replacement therapy (dialysis) $(P=0.005)$. Conclusion - Our results demonstrated that the total cost of LTx is closely related to liver disease severity scores and the development of complications.
\end{abstract}

HEADINGS - Liver transplantation. Costs and cost analysis. Hospital costs. Medical economics. Delivery of health care.

\section{INTRODUCTION}

The rising cost of health care has prompted the need for health professionals to understand and apply economic evaluations. Improving resource allocation decisions while balancing costs against benefits allows more efficient management ${ }^{(1)}$. Health care costs depend on the use of new technologies, the increase in the life expectancy of the population, the growth in the demand for health services, and the universalization of health care $^{(1)}$. In the decisionmaking process, cost evaluation is important as health organizations deal with competition, quality customer service, incorporation of state-of-the-art technology, and government funding ${ }^{(1)}$.

The first economic evaluations of liver transplantation (LTx) were conducted in the early $1990 \mathrm{~s}^{(2-9)}$ and consisted of retrospective studies (TABLE 1). Brown et al. ${ }^{(5)}$ performed the first cost evaluation of combined liver-kidney transplant. The reported high costs ${ }^{(2-9)}$ were probably due to a comprehensive analysis that included data from pretransplant to 1 year posttransplant.

Later economic evaluations have focused on the relationship between Model for End-stage Liver Disease (MELD) scores - which were included as a criterion for graft allocation, with priority based on the severity of liver disease - and procedure-related costs ${ }^{(10-12)}$. However, these studies do not describe the cost of LTx in relation to the hospital units that participate in the process. Therefore, the aim of the present study was to evaluate the cost of LTx categorized by unit specialty within a referral center in southern Brazil.

\section{METHODS}

The study was approved by the Research Ethics Committee of the institution (protocol no. 1.070.146). Consent to use retrospective data was obtained from the institution. Adult patients who underwent deceased-donor LTx between April 2013 and December 2014 were eligible for inclusion. Patients undergoing a combined liver-kidney transplant or with incomplete medical records were excluded.

The following variables were analyzed: demographic characteristics, etiology of liver disease, and severity of liver disease according to the Child-Turcotte-Pugh (CTP) score ${ }^{(13)}$ and MELD score $^{(14)}$ at the time of LTx. Data on complications occurred during hospitalization, discharge, death, and retransplantation were also collected.

\section{Identification of costs}

The hospital bill was transformed into cost by the controllers of the hospital accounting department. In order to include all incurred costs, the controllers used the full absorption costing method ${ }^{(15,16)}$. Based on this method, each hospital unit was considered a cost center to which funds are allocated to pay for services provided by the hospital's own staff or third parties (labor cost), materials and overheads, whether directly or indirectly. Indirect costs are attributed to individual cost centers by means of well-defined distribution criteria (apportionment) ${ }^{(15,16)}$.

Declared conflict of interest of all authors: none

Disclosure of funding: no funding received

Research performed at: Department of Adult Liver Transplantation, Dr Guido Cantisani Team, Irmandade da Santa Casa de Misericórdia de Porto Alegre.

${ }^{1}$ Universidade Federal de Ciências da Saúde de Porto Alegre (UFCSPA), Programa de Pós-Graduação em Medicina: Hepatologia, Porto Alegre, RS, Brasil. ${ }^{2}$ Irmandade da Santa Casa de Misericórdia de Porto Alegre, Departamento de Controladoria, Porto Alegre, RS, Brasil. ${ }^{3}$ Irmandade da Santa Casa de Misericórdia de Porto Alegre, Grupo de Transplante de Fígado, Porto Alegre, RS, Brasil.

Corresponding author: Adriane Bernardi de Souza. E-mail: adribester@gmail.com 
TABLE 1. Demographic and clinical characteristics of 109 deceased-donor liver transplant recipients.

\begin{tabular}{|c|c|}
\hline Variables & Total sample $(n=109)$ \\
\hline Age (years), mean $\pm \mathrm{SD}$ & $57.5 \pm 9.1$ \\
\hline \multicolumn{2}{|l|}{ Sex, n $(\%)$} \\
\hline Male & $68(62.4)$ \\
\hline Female & $41(37.6)$ \\
\hline \multicolumn{2}{|l|}{ Etiology, n (\%) } \\
\hline $\mathrm{HCV}+\mathrm{HCC}$ & $38(34.9)$ \\
\hline Other & $20(18.3)$ \\
\hline $\mathrm{HCV}$ & $17(15.6)$ \\
\hline $\mathrm{HCV}+$ alcohol + HCC & $12(11.0)$ \\
\hline Alcohol & $6(5.5)$ \\
\hline $\mathrm{HCV}+$ alcohol & $6(5.5)$ \\
\hline $\mathrm{HBV}+\mathrm{HCC}$ & $4(3.7)$ \\
\hline $\mathrm{HBV}$ & $3(2.8)$ \\
\hline Fulminant hepatitis & $3(2.8)$ \\
\hline \multicolumn{2}{|l|}{ CTP $(n=106), n(\%)$} \\
\hline A & $44(41.5)$ \\
\hline $\mathrm{B}$ & $42(39.6)$ \\
\hline $\mathrm{C}$ & $20(18.9)$ \\
\hline $\operatorname{MELD}(n=108)$, mean \pm SD & $24.3 \pm 6.5$ \\
\hline \multicolumn{2}{|l|}{ MELD score $(\mathrm{n}=108), \mathrm{n}(\%)$} \\
\hline$<20$ & $13(12.0)$ \\
\hline $20-25$ & $67(62.0)$ \\
\hline $26-30$ & $14(13.0)$ \\
\hline$>30$ & $14(13.0)$ \\
\hline Retransplantation, n (\%) & $3(2.8)$ \\
\hline \multicolumn{2}{|l|}{ Outcome, n (\%) } \\
\hline Discharge & $94(86.2)$ \\
\hline Death & $15(13.8)$ \\
\hline
\end{tabular}

HBV: hepatitis B virus; HCV: hepatitis C virus; HCC: hepatocellular carcinoma; CTP: Child-Turcotte-Pugh; MELD: Model for End-stage Liver Disease.

The sum of all costs generated within a cost center, divided by predetermined services provided by that hospital unit, results in unit costs, which in practice correspond to the costs of daily hospital stay, of using the operating room, of an appointment, and of an examination, among others. The cost of in-hospital procedures, such as transplantation, is related to a series of calculations, which comprise unit costs generated by the cost centers in combination with the intensity of the unit-related costs ${ }^{(16,17)}$.

Regarding materials, it is important to highlight that, in a health facility, the materials used often include medication, medicalsurgical materials, medical gases, food, and consumables, among others $^{(16)}$. In our institution, the weighted moving average is used for inventory valuation, which includes the calculation of the weighted average cost after each new material purchase ${ }^{(15)}$.

The hospital bill, from the immediate pretransplant period to hospital discharge, was obtained using the hospital management software (Phillips Tasy ${ }^{\circledR}$; Phillips Clinical Informatics, Blumenau, $\mathrm{SC}$, Brazil). The costs were then grouped into five categories:
- Immediate Pretransplant Kit: laboratory and imaging tests performed to assess the patient's clinical status or to suspend transplantation.

- Specialized Units: routine tests performed during hospitalization for LTx, specific procedures (laboratory tests, blood products, hemodialysis), specialized tests (digestive endoscopy, computed tomography, ultrasonography), physical therapy, immunosuppression, and transplant team fees according to the fee schedule of the Brazilian Unified Health System (SUS).

- Surgical Unit, Intensive Care Unit, and Inpatient Unit: all costs resulting from LTx plus personnel costs in that specific unit.

All costs were converted to U.S. dollars at an exchange rate of US\$1.00 = R\$3.38 (as of June 9, 2016), according to the Central Bank of Brazil ${ }^{(18)}$.

\section{Statistical analysis}

Quantitative variables were expressed as means and standard deviations, with the inclusion of median values in cases of skewed distribution. The Mann-Whitney and Kruskal-Wallis tests were used to compare the median values of total transplant cost. Spearman's correlation coefficient was used to assess the relationship between variables. Multivariate linear regression analysis was used to control for confounding factors. Total cost values were $\log$-transformed before analysis. The level of significance was set at $5 \%(P<0.05)$, and all analyses were performed using the Statistical Package for the Social Sciences, version 21.0.

\section{RESULTS}

Of 122 eligible liver transplant recipients, 109 were included in the analysis while 13 were excluded - $9(69.2 \%)$ due to incomplete data and $4(30.8 \%)$ due to combined liver-kidney transplant. Regarding the characteristics of the sample (TABLE 1), mean age was $57.5 \pm 9.0$ years; most patients were men $(62.4 \%)$; the most common cause of liver disease was hepatitis $\mathrm{C}$ virus (HCV) infection alone $(15.6 \%)$ or associated with alcohol and/or hepatocellular carcinoma (HCC) $(67.0 \%) ; 42.0 \%$ of patients were categorized as CTP class A; 15 patients $(13.8 \%)$ died; and 3 patients $(2.8 \%)$ underwent retransplantation.

The mean length of hospital stay was $25.0 \pm 19.0$ days, and patients spent a mean of 17.0 113.0 days in the Inpatient Unit (TABLE 2). Fifty patients had complications, the most common one being acute renal failure associated with renal replacement therapy (dialysis) (TABLE 3). The mean cost of LTx was US\$ 17,367 $\pm 9,935$. When categorized by unit specialty, Surgical Unit and Specialized Units accounted for $31.9 \%$ (US\$ 4,609) and 26.4\% (US\$ 4,296) of the total LTx cost, respectively (TABLE 4; FIGURE 1).

TABLE 2. Length of stay in different hospital units and physical therapy sessions.

\begin{tabular}{lc}
\hline \multicolumn{1}{c}{ Variables } & Total sample $(\mathrm{n}=109)$ \\
\hline Length of SU stay, hours & $6.0 \pm 1.0$ \\
Length of ICU stay, days & $8.1 \pm 10.1[5.0]$ \\
Length of IU stay, days & $17.0 \pm 12.6[15.0]$ \\
No. of physical therapy sessions & $85.6 \pm 59.2[73.0]$ \\
Total length of hospital stay, days & $25.1 \pm 19.4[22.0]$ \\
\hline
\end{tabular}

SU: Surgical Unit; ICU: Intensive Care Unit; IU: Inpatient Unit. Values are presented as mean $\pm \mathrm{SD}$ [median]. 
TABLE 3. Type and frequency of complications during hospitalization $(\mathrm{n}=85)$.

\begin{tabular}{lc}
\hline \multicolumn{1}{c}{ Complications } & n (\%) \\
\hline ARF + renal replacement therapy (dialysis) & $26(30.6)$ \\
Nosocomial infections & $17(20.0)$ \\
Massive blood transfusion & $10(11.8)$ \\
Laparotomy (hemoperitoneum) & $7(8.2)$ \\
Refractory shock & $7(8.2)$ \\
Primary graft dysfunction & $4(4.7)$ \\
Septic shock & $4(4.7)$ \\
Hemorrhagic shock & $2(2.4)$ \\
Acute coronary syndrome & $2(2.4)$ \\
Cholestatic disorders & $2(2.4)$ \\
Other & $4(4.7)$ \\
\hline
\end{tabular}

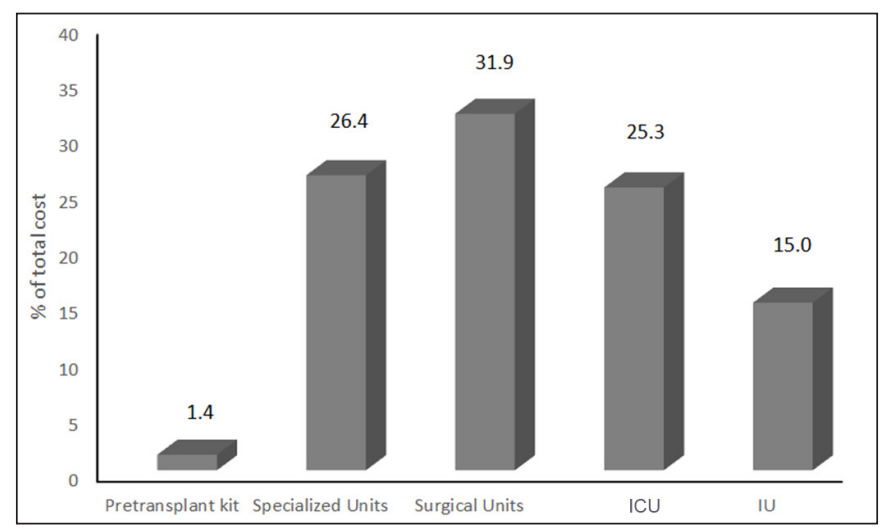

FIGURE 1. Categorization of liver transplant costs by unit specialty. ICU: intensive care unit. IU: inpatient unit.

TABLE 4. Costs in the different hospital units that participate in the liver transplantation process.

\begin{tabular}{|c|c|c|}
\hline \multirow{2}{*}{ Unit specialty } & \multicolumn{2}{|c|}{ Costs } \\
\hline & In $\mathrm{R} \$$ mean $\pm \mathrm{SD}$ [median] & In US $\$ \$^{\#}$ mean $\pm \mathrm{SD}$ [median] \\
\hline Pretransplant kit & $680.0 \pm 0.0[680.0]$ & $201.0 \pm 0.0[201.0]$ \\
\hline Laboratory tests & $2,299.0 \pm 1,131.0[2,044.0]$ & $680.0 \pm 335.0[605.0]$ \\
\hline Imaging studies & $842.0 \pm 715.0[616.0]$ & $249.0 \pm 211.0[182.0]$ \\
\hline Specialized tests & $1,142.0 \pm 1,744.0[994.0]$ & $338.0 \pm 516.0[294.0]$ \\
\hline Physical therapy & $1,159.0 \pm 802.0[988.0]$ & $343.0 \pm 237.0[292.0]$ \\
\hline Immunosuppression & $1,188.0 \pm 1,906.0[615.0]$ & $351.0 \pm 564.0[182.0]$ \\
\hline Transplant team fees & $7,182.0 \pm 0.0[7,182.0]$ & $2,125.0 \pm 0.0[2,125.0]$ \\
\hline Total & $14,523.0 \pm 4,693.0[12,728.0]$ & $4,296.0 \pm 1,388.0[3,765.0]$ \\
\hline Total length of SU stay (hours) & $10,906.0 \pm 1,994.0[10,884.0]$ & $3,227.0 \pm 590.0[3,220.0]$ \\
\hline Medication & $1,438.0 \pm 1,930.0[620.0]$ & $425.0 \pm 571.0[183.0]$ \\
\hline Orthoses and prostheses & $1,319.0 \pm 369.0[1,223.0]$ & $390.0 \pm 109.0[362.0]$ \\
\hline Total & $15,578.0 \pm 3,482.0[15,355.0]$ & $4,609.0 \pm 1,030.0[4,543.0]$ \\
\hline \multicolumn{3}{|l|}{ Intensive Care Unit (ICU) } \\
\hline Total length of ICU stay (days) & $15,112.0 \pm 18,101.0[9,500.0]$ & $4,471.0 \pm 5,455.0[2,811.0]$ \\
\hline Medication & $4,116.0 \pm 8,596.0[1,139.0]$ & $1,218.0 \pm 2,543.0[337.0]$ \\
\hline Materials & $512.0 \pm 737.0[258.0]$ & $151.0 \pm 218.0[76.0]$ \\
\hline Total & $19,740.0 \pm 26,086.0[12,185.0]$ & $5,840.0 \pm 7,718.0[3,605.0]$ \\
\hline \multicolumn{3}{|l|}{ Inpatient Unit (IU) } \\
\hline Total liver transplant cost & $58,699.0 \pm 33,581.0[50,885.0]$ & $17,367.0 \pm 9,935.0[15,055.0]$ \\
\hline
\end{tabular}

\footnotetext{
"exchange rate - US $\$ 1,00=\mathrm{R} \$ 3,38$ (as of June 9, 2016).
} 
There was no significant association between LTx cost and etiology of liver disease ( $P=0.24$ ) (TABLE 5). Patients with MELD scores of 26-30 generated the same costs as those of retransplantation. Fulminant hepatitis had a mean cost per patient of US\$21,242. Patients with chronic diseases had costs of US\$12,393 for hepatitis $\mathrm{B}$ virus (HBV) infection and US\$23,736 for $\mathrm{HCV}$ infection. Patients with $\mathrm{HCV}$ infection and patients with CTP class $\mathrm{C}$ had higher costs.
There was no significant cost difference between patients with HCC (US\$ 16,542) and without HCC (US\$ 18,177) $(P=0.48)$.

Significant cost differences were found between CTP classes (TABLE 5), as follows: on average, US\$ 14,330 for patients with CTP class A, US\$ 18,400 for CTP class B, and US\$22,823 for CTP class $C(P=0.002)$. The following complications contributed to significantly increase the total LTx cost: septic shock $(P=0.006)$;

TABLE 5. Relationship between costs and clinical variables.

\begin{tabular}{lccc}
\hline & & & Total liver transplant cost \\
\cline { 3 - 4 } Variables & $\mathbf{n}$ & In R\$ mean \pm SD [median] & In US\$\#\# mean \pm SD [median] \\
\hline Etiology & 3 & $41,890.0 \pm 18,067.0[32,245.0]$ & $0.24^{*}$ \\
HBV & 4 & $74,648.0 \pm 36,947.0[62,358.0]$ & $22,085.0 \pm 10,798.0[18,449.0]$ \\
HBV + HCC & 17 & $80,227.0 \pm 65,220.0[53,657.0]$ & $23,736.0 \pm 19,296.0[15,875.0]$ \\
HCV & 38 & $54,887.0 \pm 26,218.0[45,489.0]$ & $16,239.0 \pm 7,757.0[13,458.0]$ \\
HCV + HCC & 6 & $49,432.0 \pm 9,721.0[46,910.0]$ & $14,625.0 \pm 2,876.0[13,879.0]$ \\
HCV + alcohol & 12 & $52,906.0 \pm 20,910.0[45,587.0]$ & $15,653.0 \pm 6,186.0[13,487.0]$ \\
HCV + alcohol + HCC & 6 & $58,801.0 \pm 24,010.0[47,673.0]$ & $17,397.0 \pm 7,103.0[14,104.0]$ \\
Alcohol & 3 & $71,797.0 \pm 10,371.0[72,643.0]$ & $21,242.0 \pm 3,068.0[21,492.0]$ \\
Fulminant hepatitis & 20 & $51,238.0 \pm 11,074.0[53,557.0]$ & $15,159.0 \pm 3,276.0[15,845.0]$ \\
Other & &
\end{tabular}

HCC

$\begin{array}{lll}\text { Yes } & 54 & 55,911.0 \pm 26,023.0[45,916.0] \\ \text { No } & 55 & 61,438.0 \pm 39,690.0[53,401.0]\end{array}$

$\mathrm{CTP}^{\#}$

$\begin{array}{lll}\text { A } & 44 & 48,434.0 \pm 13,524.0[45,092.0]^{\mathrm{a}} \\ \text { B } & 42 & 62,193.0 \pm 29,095.0[53,478.0]^{\mathrm{b}} \\ \text { C } & 20 & 77,142.0 \pm 58,847.0[60,923.0]^{\mathrm{b}}\end{array}$

MELD score ${ }^{\# \#}$

$\begin{array}{lll}<20 & 13 & 47,419.0 \pm 10,091.0[43,094.0] \\ 20-25 & 67 & 56,816.0 \pm 24,506.0[47,880.0] \\ 26-30 & 14 & 61,100.0 \pm 28,141.0[55,375.0] \\ >30 & 14 & 75,619.0 \pm 70,521.0[58,943.0]\end{array}$

Retransplantation

$\begin{array}{ccc}\text { Yes } & 3 & 62,051.0 \pm 4,552.0[64,382.0] \\ \text { No } & 106 & 58,605.0 \pm 34,047.0[48,540.0]\end{array}$

Outcome

Discharge $94 \quad 56,863.0 \pm 31,135.0[51,549.0]$

Death 15

$70,211.0 \pm 45,776.0[44,218.0]$

Complications

Yes $\quad 50$

No
$69,662.0 \pm 45,286.0[56,500.0]$ $49,404.0 \pm 13,260.0[45,572.0]$
$0.48 * *$

$16,542.0 \pm 7,765.0[13,585.0]$

$18,177.0 \pm 11,636.0[15,799.0]$

$0.002 *$

$14,330.0 \pm 4,001.0[13,341.0]^{\mathrm{a}}$

$18,400.0 \pm 8,608.0[15,822.0]^{\mathrm{b}}$

$22,823.0 \pm 17,410.0[18,025.0]^{\mathrm{b}}$

$0.38 *$

$14,029.0 \pm 2,985.0[12,750.0]$

$16,809.0 \pm 7,250.0[14,166.0]$

$18,077.0 \pm 8,326.0[16,383.0]$

$22,372.0 \pm 20,864.0$ [17,439.0]

$0.12 * *$

$18,358.0 \pm 1,347.0[19,048.0]$

$17,339.0 \pm 10,073.0$ [14,361.0]

$1.00 * *$

$16,823.0 \pm 9,211.0[15,251.0]$

$20,772.0 \pm 13,543.0[13,082.0]$

$0.002 * *$

$20,610.0 \pm 13,398.0$ [16,716.0] $14,617.0 \pm 3,923.0$ [13,483.0]

HBV: hepatitis B virus; HCV: hepatitis C virus; HCC: hepatocellular carcinoma; CTP: Child-Turcotte-Pugh; MELD: Model for End-stage Liver Disease. ${ }^{a, b}$ Means with the same superscript letters are not significantly different at the 5\% significance level determined by the Mann-Whitney test; * Kruskal-Wallis test; ** Mann-Whitney test; " available for 106 patients; * "\# available for 108 patients; ${ }^{\sharp \# \#}$ exchange rate - US $\$ 1.00=\mathrm{R} \$ 3.38$ (as of June 9, 2016). 
acute coronary syndrome $(P=0.019)$; prolonged hospitalization, renal injury, mechanical ventilation, and tracheostomy $(P=0.012)$; massive blood transfusion $(P=0.007)$; posttransplant laparotomy $(P=0.001)$; and acute renal failure associated with renal replacement therapy (dialysis) $(P=0.005)$ (FIGURE 2).

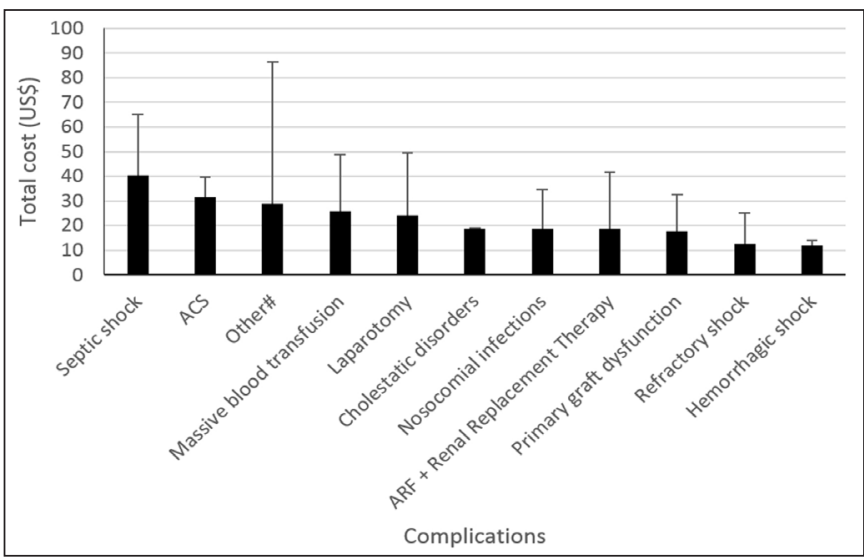

FIGURE 2. Relationship between complications and liver transplant costs. ACS: acute coronary syndrome; ARF: acute renal failure. \# Prolonged hospitalization, tracheostomy, non-dialysis renal injury, and prolonged mechanical ventilation. * Significantly higher costs than other complications as a whole at the 5\% significance level determined by the Mann-Whitney test.

In the multivariate analysis, CTP and complications remained associated with total LTx cost. According to the standardized regression coefficient $(\beta)$, the factor that most contributed to the increase in total LTx cost was CTP class C (TABLE 6).

TABLE 6. Results of multivariate linear regression analysis for factors independently associated with total cost*.

\begin{tabular}{lccc}
\hline \multicolumn{1}{c}{ Variables } & $95 \%$ CI & Beta $(\boldsymbol{\beta})^{*}$ & $P^{* *}$ \\
\hline CTP & 0.0 & & \\
A & $0.18(6.2$ to 0.32$)$ & 0.227 & 0.02 \\
B & $0.33(6.2$ to 0.51$)$ & 0.340 & 0.001 \\
C & $0.25(-0.15$ to 0.64$)$ & 0.107 & 0.22 \\
Retransplantation (n=3) & 0.0 & & \\
Yes & & & \\
No & $0.21(0.08$ to 0.34$)$ & 0.275 & 0.002 \\
Complications & 0.0 & & \\
Yes & &
\end{tabular}

\section{DISCUSSION}

This is the first study in Latin America to comprehensively evaluate the cost of LTx categorized by hospital unit and its correlation with clinical variables in a referral center in southern Brazil. The cost generated in the different stages of LTx reflects the true value that is invested by the center in the process regardless of the source of payment. Our findings are consistent with those of Portela et al. ${ }^{(19)}$ e Boerr et al. ${ }^{(20)}$ in terms of mean patient age at the time of transplantation, sex, and etiology of liver disease. In our sample, the most common etiology was HCV infection associated with HCC (34.9\%), similar to Ferraz et al. ${ }^{(21)}$ and Boerr et al. ${ }^{(20)}$, while Akarsu et al. ${ }^{(22)}$ reported HBV infection.

In the present study, most patients were CTP class A, while Akarsu et al. ${ }^{(22)}$ found that CTP class B was the most prevalent. Most patients had a MELD score of 20-25 (62\%), consistent with the findings of Boerr et al. ${ }^{(20)}(25 \pm 5 ; P=0.01)$. The mean operative time was $6.0 \pm 1$ hours, shorter than that observed by Portela et al. ${ }^{(19)}$. The length of hospital stay (25.0 \pm 19.0 days) was also shorter than that reported by Portela et al. ${ }^{(19)}$ and Ferraz et al. ${ }^{(21)}$, but longer than that observed by Boerr et al. ${ }^{(20)}$. Our patients received a mean of 85.6 physical therapy sessions, but no previous study has evaluated this variable. The most common complication was acute renal failure associated with renal replacement therapy (dialysis), which is consistent with the findings of Portela et al. ${ }^{(21)}$. The mean cost of LTx was US\$17,367, which is lower than that reported in Argentina (US\$ 33,461) $)^{(20)}$ and in Turkey (US\$ 27,582) ${ }^{(22)}$. The difference is probably due to Brazilian Real devaluation against U.S. Dollar and to procedure-related costs ${ }^{(20-22)}$.

Government and hospital economic policies, available technologies, donor availability, and severity of liver disease may affect the cost of LTx categorized by hospital unit ${ }^{(20-23)}$. In our study, the most costly units were the Surgical Unit, Specialized Units, and Intensive Care Unit. Comparison of our findings with those reported in the literature, however, is a difficult task because of the use of different methods. Akarsu et al. ${ }^{(22)}$ concluded that medication, surgical unit, and laboratory tests were the most expensive items of LTx. For Boerr et al. ${ }^{(20)}$, physician fees and therapeutic interventions were the most expensive items of LTx. However, those studies did not provide detailed information for each unit involved in the LTx process. Portela et al. ${ }^{(19)}$ performed the analysis only at the hospital level.

LTx in patients with severe liver disease, according to the CTP classification, has a higher cost, but when the MELD score is considered, the results are conflicting ${ }^{(20-22)}$. Akarsu et al. ${ }^{(22)}$ found no association between LTx cost and MELD score, while Boerr et al. ${ }^{(20)}$ and Buchanan et al. ${ }^{(23)}$ showed a direct association between them.

The etiology of liver disease has been associated with LTx cost in the literature. Higher LTx cost was associated with chronic $\mathrm{HCV}$ infection according to Axelrod et al. ${ }^{(24)}$ and with chronic HBV infection complicated by HCC according to Akarsu et al. ${ }^{(22)}$. The present results, nonetheless, suggest that the etiology of liver disease is not significantly associated with LTx cost, but cases of $\mathrm{HCV}$ infection and CTP class $\mathrm{C}$ have higher costs. This non-causal association is interesting because most cases of CTP class $\mathrm{C}$ were patients with HCV infection and without $\mathrm{HCC}$, thus with higher MELD score and more complications. However, LTx for acute diseases had a high cost probably due to the clinical course, severity, and complications of the disease.

In the United States, health insurance companies are responsible for paying for the procedure. In 2012, the U.S. Supreme Court passed a law that allows people without health insurance to benefit from LTx with costs covered by the State according to Medicare coverage $^{(25)}$. In Spain, transplants are covered by the National Transplant Organization (ONT) linked to the Ministry of Health ${ }^{(26)}$.

In Brazil, the LTx procedure is 100\% funded by the SUS with financial incentives for institutions to promote organ donation and transplantation. In addition to paying for all procedure-related expenses, the SUS also provides medication ${ }^{(27)}$. Approximately $95 \%$ of transplant procedures are performed through the SUS, qualifying it as the largest public transplantation program in the 
world. The Institute for Applied Economic Research ${ }^{(28)}$ and, later, the Federal Court of Accounts ${ }^{(29)}$ have shown that public investment in transplantation, including procedures and associated pharmacotherapy, increased from R $\$ 404.4$ million in 2004 to $\mathrm{R} \$$ 521.8 million in $2005^{(29)}$. To increase the number of transplants and reduce the number of patients on the waiting list, the Brazilian Ministry of Health issued Ordinance No. 845, dated of May 2, $2012^{(30)}$, which defines new rules for providing financial incentives for institutions that perform these procedures ${ }^{(30)}$. As a result, in 2013, SUS invested R \$ 1.4 billion in surgeries, organ donation, and organ procurement ${ }^{(30)}$. Currently, the SUS transfers R $\$ 68,839$ to the transplantation institutions for LTx. The amount of $\mathrm{R} \$ 61,656$ is intended to cover hospital services and $\mathrm{R} \$ 7,182$ to cover physician professional fees, according to existing SUS fee schedules ${ }^{(31)}$.

Portela et al. ${ }^{(19)}$ conducted a study in the state of Ceará, northeastern Brazil, involving 62 patients and reported a mean cost of US\$ 20,605 for LTx. They used a method similar to the one described in the present study, but the sample size and the non-inclusion of complications and professional fees of physical therapists in the total cost may have not reflected the true value. In our study, physical therapy fees accounted for $1.9 \%$ of the total cost.

Coelho et al. ${ }^{(32)}$ conducted a study in the state of Paraná, southern Brazil, involving 24 patients undergoing 25 LTx procedures and found an average cost for LTx of US\$21,505, including organ procurement expenses, but excluding professional fees of the multidisciplinary team participating in the procedure. Ferraz et al. ${ }^{(21)}$ estimated the cost of LTx in four patients in the state of Pernambuco, northeastern Brazil, and found a total cost of US\$ 8,874, excluding professional team fees and the impact of complications.
The major limitations of this study are its retrospective nature and the fact that it was conducted in a single transplant center.

\section{CONCLUSION}

Our results demonstrated that the total cost of LTx is closely related to liver disease severity scores and the development of complications. The lack of a standard method for and items to be evaluated and included in total cost estimation is a determining factor in the final value. The different hospital purchasing policies may influence the final value, but they may also provide a basis for establishing public policies or implementing programs involving economic evaluations and cost-benefit, cost-effectiveness, and cost-utility analyses of high-cost procedures performed in public institutions, which unfortunately often work on a limited budget.

\section{Authors' contribution}

Souza AB and Marroni CA: conception and design, analysis and interpretation, overall responsibility. Rodriguez S: data collection. Souza AB: data collection, writing the article. Marroni CA, Motta FL, Brandão ABM: critical revision of the article.

All authors have read and approved the final version of the article.

\section{Orcid}

Adriane B de Souza. Orcid: 0000-0002-1851-8954.

Santiago Rodriguez. Orcid: 0000-0001-8610-3622.

Fábio Luís da Motta. Orcid: 0000-0001-9544-4699.

Ajacio B de Mello Brandão. Orcid: 0000-0001-8411-5654.

Claudio Augusto Marroni. Orcid: 0000-0002-1718-6548.

Souza AB, Rodriguez S, Motta FL, Brandão ABM, Marroni CA. O custo do transplante hepático adulto em um centro de referência na região sul do Brasil. Arq Gastroenterol. 2019;56(2):165-71.

RESUMO - Contexto - O transplante hepático (TxH) é o principal e definitivo tratamento de casos agudos ou crônicos de doenças hepáticas avançadas ou terminais. Poucos estudos têm avaliado o custo real do TxH categorizado por setores hospitalares. Objetivo - Avaliar o custo do TxH categorizado por especialidade da unidade em um centro de referência na região sul do Brasil. Métodos-Analisamos retrospectivamente os prontuários de 109 pacientes submetidos a TxH entre abril de 2013 e dezembro de 2014. Foram coletados dados sobre características demográficas, etiologia da doença hepática e gravidade da doença hepática de acordo com os escores Child-Turcotte-Pugh (CTP) e Model for End-stage Liver Disease (MELD) no momento do TxH. A conta hospitalar foi transformada em custo pelo método de custeio por absorção integral, e os custos foram agrupados em cinco categorias: Kit Pré-Transplante Imediato; Unidades Especializadas; Centro Cirúrgico; Unidade de Terapia Intensiva; e Unidade de Internação. Resultados - O custo médio total do TxH foi de US\$ 17.367. O Centro Cirúrgico, as Unidades Especializadas e a Unidade de Terapia Intensiva responderam por $31,9 \%, 26,4 \%$ e $25,3 \%$ dos custos, respectivamente. A análise multivariada demonstrou que o custo total do TxH se associou significativamente ao escore CTP classe $\mathrm{C}(P=0,001)$ e ao desenvolvimento de intercorrências $(P=0,002)$. As seguintes intercorrências contribuíram para aumentar significativamente o custo do TxH: choque séptico $(P=0,006)$, politransfusão sanguínea $(P=0,007)$ e insuficiência renal aguda associada à terapia renal substitutiva (diálise) $(P=0,005)$. Conclusão - Nossos resultados demonstraram que o custo total do TxH guarda uma estreita relação com os escores de gravidade da doença hepática e com o desenvolvimento de intercorrências.

DESCRITORES - Transplante de fígado. Custos e análise de custo. Custos hospitalares. Economia médica. Assistência à saúde. 


\section{REFERENCES}

1. Francisco IMF, Castilho V. A enfermagem e o gerenciamento de custos. Rev Esc Enferm USP. 2002;36:240-4.

2. Gilbert JR, Pascual M, Schoenfeld DA, Rubin RH, Delmonico FL, Cosimi $\mathrm{AB}$. Evolving trends in liver transplantation: an outcome and charge analysis. Transplantation. 1999;67:246-53.

3. Showstack J, Katz PP, Lake JR, Brown RS, Dudley RA, Belle S, et al. Resource utilization in liver transplantation: effects of patient characteristics and clinical practice. NIDDK Liver Transplantation Database Group. JAMA. 1999;281:1381-6.

4. Rufat P, Fourquet F, Conti F, Le Gales C, Houssin D, Coste J. Cost and outcomes of liver transplantation in adults: a prospective, 1-year, follow-up study. Transplantation. 1999;68:76-83.

5. Brown Jr RS, Lake JR, Ascher NL, Emond JC, Roberts JP. Predictors of the cost liver transplantation. Liver Transpl. 1998;4:170-6.

6. Markmann JF, Markmann JW, Markmann DA, Bacquerizo A, Singer J, Holt CD, et al. Preoperative factors associated with outcome and their impact on resource use in 1148 consecutive primary liver transplants. Transplantation. 2001;72:1113-22.

7. van Agthoven M, Metselaar HJ, Tilanus HW, Man RA, IJzermans JN, van Ineveld BM. A comparison of the cost and effects of liver transplantation for acute and for chronic liver failure. Transpl Int. 2001;14:87-94.

8. Filipponi F, Pisati R, Cavicchini G, Ulivieri MI, Ferrara R, Mosca F. Cost and outcome analysis and cost determinants of liver transplantation in a European National Health Service Hospital. Transplantation. 2003;75:1731-6.

9. Trotter JF, Mackenzie S, Wachs M, Bak T, Steinberg T, Polsky P, et al. Comprehensive cost comparison of adult-adult right hepatic lobe living-donor liver transplantation with cadaveric transplantation. Transplantation. 2003;75:473-6.

10. O'Leary JG, Lepe R, Davis GL. Indications for liver transplantation. Gastroenterology. 2008;134:1764-76.

11. Malinchoc M, Kamath PS, Gordon FD, Peine CJ, Rank J, ter Borg PC. A model to predict poor survival in patients undergoing transjugular intrahepatic portosystemic shunts. Hepatology. 2000;31:864-71.

12. Wiesner R, Edwards E, Freeman R, Harper A, Kim R, Kamath P, et al. Model for end-stage liver disease (MELD) and allocation of donor livers. Gastroenterology. 2003; 124:91-6.

13. Pugh RN, Murray-Lyon IM, Dawson JL, Pietroni MC, Williams R. Transection of the oesophagus for bleeding oesophageal varices. Br J Surg. 1973;60:646-9.

14. Wiesner RH, McDiarmid SV, Kamath PS, Edwards EB, Malinchoc M, Kremers WK, et al. MELD and PELD: application of survival models to liver allocation. Liver Transpl. 2001;7:567-80.

15. Martins E. Contabilidade de custos. 9th ed. São Paulo: Atlas; 2003.

16. Matos, AJ. Gestão de custos hospitalares. São Paulo: STS; 2002.

17. Ching, HY. Manual de custos de instituições de saúde. Sistemas tradicionais de custos e sistema de custeio baseado em atividades (ABC). 2nd ed. São Paulo: Atlas; 2001
18. Banco Central do Brasil. Conversão de moedas [Internet]. [cited 2019 Jan 31]. Available from: http://www4.bcb.gov.br/pec/conversao/conversao.asp

19. Portela MP, Neri EDR, Fonteles MMF, Garcia JHP, Fernandes MEP. O custo do transplante hepático em um hospital universitário do Brasil. Rev Assoc Med Bras. 2010;56:322-6.

20. Boerr E, Anders M, Mella J, Quiñonez E, Goldaracena N, Orozco F, et al. [Cost analysis of liver transplantation in a community hospital: association with the Model for End-stage Liver Disease, a prognostic index to prioritize the most severe patients]. [Article in Spanish]. Gastroenterol Hepatol. 2013;36:1-6.

21. Ferraz AA, Lopes EP, Sette MJ, Godoy MM, Lima MH, Araújo Júnior JG, et al. [Liver transplantation cost analysis at the Hospital das Clínicas da Universidade Federal de Pernambuco]. Rev Bras Saúde Matern Infant. 2002;2:313-8.

22. Akarsu M, Matur M, Karademir S, Unek T, Astarcioglu I. Cost analysis of liver transplantation in Turkey. Transplant Proc. 2011;43:3783-8.

23. Buchanan P, Dzebisashvili N, Lentine KL, Axelrod DA, Schnitzler MA, Salvalaggio PR. Liver transplantation cost in the model for end-stage liver disease era: looking beyond the transplantation admission. Liver Transpl. 2009;15:1270-7.

24. Axelrod DA, Koffron AJ, Baker T, Al-Saden P, Dixler I, McNatt G, et al. The economic impact of MELD on liver transplant centers. Am J Transplant. 2006;5:2297-301

25. U.S. Centers for Medicare \&Medicaid Services. Medicare [Internet]. [cited 2019 Jan 31]. Available from: https://www.medicare.gov/

26. Gobierno de España. Ministerio de la Presidencia. Boletín Oficial del Estado [Internet]. [cited 2019 Jan 31]. Available from: https://www.boe.es/diario_boe/ txt.php?id=BOE-A-2009-18977

27. Brasil. Ministério da Saúde. Portaria N N 510, de 27 de novembro de 2010 [Internet]. [cited 2019 Jan 31]. Available from http://bvsms.saude.gov.br/bvs/saudelegis/ sas/2010/prt0510_27_11_2010.html

28. Marinho A. Estado de uma Nação: textos de apoio a situação dos transplantes de órgãos no Brasil. Texto para discussão No 1389. Brasília (DF): IPEA; 2009.

29. Brasil. Tribunal de Contas da União. Relatório de avaliação de programa: programa doação, captação e transplante de órgãos e tecidos. Brasília (DF): TCU; 2006.

30. Brasil. Ministério da Saúde. Portaria $n^{\circ} 845$, de 02 de maio de 2012 [Internet]. [cited 2019 Jan 31]. Available from: http://www.abto.org.br/abtov03/Upload/file/ portaria.pdf.

31. Ministério da Saúde. SIGTAP - Sistema de Gerenciamento da Tabela de Procedimentos, Medicamentos e OPM do SUS [Internet]. Brasília (DF): MS; 2016. [Internet]. [cited 2019 Jan 31]. Available from: http://sigtap.datasus.gov.br/ tabela-unificada/app/sec/inicio.jsp.

32. Coelho JUC, Wiederkehr JC, Lacerda MA, Campos ACL, Zeni Neto C, Matias JEF, et al. Custo de transplante hepático no Hospital de Clinicas da Universidade Federal do Paraná. Rev Ass Med Bras. 1997;43:53-7. 